\title{
Evaluation Of Individual Student Planning in Junior High School Yogyakarta City: Discrepancy Model
}

\author{
Caraka Putra Bhakti, Agus Ria Kumara \\ Departement Guidance and Counseling \\ Universitas Ahmad Dahlan \\ Yogyakarta, Indonessia \\ caraka.pb@bk.uad.ac.id, agus.kumara@bk.uad.ac.id
}

\author{
Budi Astuti, Suwarjo \\ Departement Guidance and Counseling \\ Universitas Negeri Yogyakarta \\ Yogyakarta, Indonesia \\ budi_astuti@uny.ac.id, suwarjo@uny.ac.id
}

\begin{abstract}
This electronic document is a "live" template and already defines the components of your paper [title, text, heads, etc.] in its style sheet. This study aims to determine the discrepancy between the performance of individual student planning of Junior High School in Yogyakarta with standards. This study uses a standard of Guidelines for Performance Based on regulation Permendikbud no 111 2014[1] and ASCA National Model third edition 2012. Standard reads, "individual student planning consists of ongoing systemic activities designed to help students establish personal goals and develop future plans, such as individual learning plans and graduation plans. School counselors use these activities to help all students plan, monitor and manage their own learning as well as to achieve academic, career and personal/social competencies aligned with the school counseling core curriculum". This study is an evaluation research. Evaluations were performed in this study using a discrepancy model. The approach used is a systems approach that is focused on appraisal, advisement, placement, and career development of individual student planning. Based on the analysis of the results of the evaluation, individual student planning in Junior High School in Yogyakarta is still far from standard. The results of this study recommend to counselors to improve the quality of the individual student planning, so give a positive impact on students success study.
\end{abstract}

\section{Keywords—individual student planning; discrepancy}

\section{INTRODUCTION}

Academic and college/career planning provide all students with the opportunity to identify strengths, areas in need of improvement, and areas of interest early in their education, so students and their families can set postsecondary goals and make informed choices to support students in achieving goals $8,9,10,11$. It because students is the proactive ability to investigate future career ways, and the plans for study and decisions based on one's knowledge, talents, interests, and capabilities $^{25,27}$. From planning the career or study base on abilities, students will process of finding the best possible match of a there self with a many kind of work or study ${ }^{11,22}$. That is the reason why academic and career planning is important.

The focus of academic and career planning is threefold: to help students acquire the skills to achieve academic success, to make connections between school and life experiences, and to acquire knowledge and skills to be college- and/or career-ready upon high school graduation. According to Savitz-Romer and Bouffary[2], academic and career planning includes supporting a variety of developmental processes (e.g., self-concept, motivation, goal setting, self-regulation, identity development and relationship development)23. From that activities, the goals are to help students develop their own life career plan, their self-efficacy will be enhance, and improve life satisfaction26. All Activities are important to help students develop there future to make there future better.

ASCA said, individual student planning consists of ongoing systemic activities designed to help students establish personal goals and develop future plans, such as individual learning plans and graduation plans4. Nelson also said that, individual student planning consists of school counselors helping students to help students with there personal goals and make future plans20. Vinci explain more about the purpose about individual student planning that individual student planning is to provide all students with activities to help them assess, plan, monitor, and manage their personal, academic, social, and career development in a positive manner21. School counselors use these activities to help all students plan, monitor and manage their own learning as well as to achieve academic, career and personal/social competencies aligned with the school counseling core curriculum.

Individual student planning is part guidance and counseling comprehensive program. It because school counselors should create activities (e.g., individual student planning, career fairs, jobs shadows, and guest speakers from different occupational areas) to develop students career goals6. And also for some students, the counselors give the support system those students to towards career ready and finishing school as college3. Implementation of individual student planning in accordance with applicable regulations can be implemented properly if supported by intact competencies in guidance and counseling teachers Implementation of guidance and counseling programs required mastery of the concept of intact and skill that qualified. According to Studer to implement a comprehensive counseling and counseling program that is completely consistent with developmental theory requires a truly trained counselor and master the theory of development)5. In addition to strengthening the knowledge side, guidance and counseling teachers need to be equipped with a comprehensive set of training in implementing comprehensive guidance and 
counseling programs. This view is in line with the results of Burkard, A., Gillen, M., Martinez, M., \& Skytte, S. research that the practice training of comprehensive guidance and counseling programs is effective in improving the implementation of counseling and guidance programs at high schools in Winconsin, America7.

The student's specialization service is a guiding area of the guidance and counseling profession, which is covered by individual student planning services1. Individual planning service activities are not merely concentrated but conceptually by Gysbers \& Henderson[3] explains that individual planning services are systematic activities designed to help learners understand and take action to develop future plans16. The strategy of implementation services can be in both group and individual formats. The undertaken activities include the recognition of personal character, measure the level of achievement of his goals, and take decisions that reflect his self-planning.

Johnson[4] said, emphasized that individual student planning helps students to know their potential, career exploration, and career development8,17. So that the components of individual planning services are considered important to be implemented comprehensively. Makrifah so far individual student planning services are limited to providing information on types of work and further study options 19.

Based on the above study it can be concluded that individual planning is part of comprehensive guidance and counseling program. The goal of research is evaluation of individual student planning in junior high school.

\section{METHOD}

This study is the evaluation. Evaluations were conducted in this study using a discrepancy model that helps administrators make decisions13. The approach used is a systems approach that is focused on the planning, implementation and evaluation of individual planning services in Middle school in Yogyakarta. Discrepancy model is an evaluation model developed by Malcom Provus. Provus defines evaluation as a process of (1) determine the program standards; (2) determining the difference between the performance standards; (3) using a mismatch as a material to change the performance or standard program13. Free to evaluate the individual planning services refers to the Cobia and Henderson[5], and ASCA[6] indicator invidiual implementation planning services include: appraisal, advisement, plecemet, and career development16,5. Descripted statistical data analysis and presentation of data using the percentage tab.

\section{RESULT AND DISCUSSION}

The results of the study at 20 schools study subjects showed the following results of the study.

\begin{tabular}{|l|l|l|l|}
\hline $\begin{array}{l}\text { Individual } \\
\text { components } \\
\text { student planning } \\
\text { service }\end{array}$ & $\begin{array}{l}\text { Done } \\
\text { according } \\
\text { to } \\
\text { Standard }\end{array}$ & $\begin{array}{l}\text { Done } \\
\text { standard } \\
\text { approach }\end{array}$ & $\begin{array}{l}\text { Far from the } \\
\text { standard }\end{array}$ \\
\hline Appraisal & 40 & 50 & 10 \\
\hline
\end{tabular}

\begin{tabular}{|l|l|l|l|} 
advisement & 25 & 60 & 15 \\
\hline placement & 30 & 40 & 20 \\
\hline $\begin{array}{l}\text { Career } \\
\text { Development }\end{array}$ & 30 & 50 & 20 \\
\hline
\end{tabular}

The results showed that the activities of individual planning service delivery has not run according to the standard. The research data shows appraisal services has been completed according to the standard 40\%,50\% implemented a standard approach and away from the standard 10\%. At the advisement services are implemented according to the standard 25\%,60\% implemented a standard approach and away from the standard $15 \%$. In placement services are implemented according to the standard 30\%, 40\% implemented a standard approach and away from the standard $20 \%$. In career development services are implemented according to the standard 40\%, 50\% implemented a standard approach and away from the standard $20 \%$.

In more detail, an appraisal service that has not done well is to collect data students' attitudes and achievement data and non-academic. The majority of data is done routinely in school aptitude test data collected interest in cooperation with the bureau psychology and instrument data needs for the preparation of guidance and counseling program.

At the individual components, namely planning student advisement that the activity has not done well is exploring plans further studies student students based on student data in the portfolio and provide consultation on educational planning for students based on student data in the portfolio. Advisement activities fulfilled: (1) Introduce students about the types of secondary school, (2) Introduce the students about the subjects taught in secondary school, (3) Introduce the students about methods / techniques of learning in secondary school

In the planning of individual components, namely placement student, who has not done well, namely (1) Involve alumni to share experiences about the registration process until the process of education at secondary school for students, (2) involve the public relations department in secondary schools certain to provide orientation and information about how to register, registration, school achievement and school conditions the other (promotional). (3) involve experts (ex. a successful entrepreneur, teacher, doctors, police) to share experiences about the process of secondary school education and the achievement of a future career. Activities that have been performing well on the activity (1) Provide information about the kinds of selection of further education at universities for students according to the state itself, (2) Provide information about the prospects of selection of further education at universities for students in accordance with the situation himself, (3) provide insight into the preparation of selection enrollment, test / interview and the cost of college education

At the individual components, namely planning student career development, which has not done well, namely on the activity (1) To provide knowledge to students about the relationship between learning by doing. (2) To develop students 'skills in understanding and using information on further studies / career, (3) develop students' skills in making 
decisions about further studies / career, (4) Assist students in identifying jobs that are relevant to the availability of personal and professional students, (5) Develop students' awareness of academic achievement skills relevant to the demands of work14,15.

The effectiveness of the successful implementation of student individual planning in the US has been proven in several related research reports. Breaking Ranks in the Middle Also emphasized individual student planning. The report recommended that sixth or seventh graders and Reviews their parents be Introduced to planning for Reviews their education and beyond. The report stressed the need for students to meet frequently and meaningfully with an adult to plan Reviews their development and review. Kalchik and Oetle[7] stressed that importance of individual career plans for student29. They Examined the using of programs of study and career pathways as structures to guide the student as they developed and used individual career plans. They also Described a number of implementation issues, Including the challenges Involved in the implementation process.

While individual planning implementation in Indonesia in line with government regulations. There is some research has been done to develop media student services in individual service planning, research Zamroni[8] the development of Interactive Multimedia Career Guidance To Improve Skills Careers Making decisions Specialization program Junior High School Students28. Research Fandini[9] Development as Adobe Flash Media Information Services Specialization High School Advanced Studies and equivalent to Grade IX SMPN 5 Sidoarjo12. Research makrifah[10] concerning Package Development Specialization in Classical Guidance Service for Students in junior high19. Research Atmaja[11] using the module untukk improve students' career planning in secondary schools2. Research Lapan[12] about Comprehensive school counseling programs: In some schools for some students but not in all schools for all students18. Research Whiston[13] about Review of school counseling outcome research 24 .

The development of individualized student planning services in Indonesia needs to be comprehensively designed. Regulation and a set of support implementation of specialization already exist, but need to be developed better. Specialization activities are not only implemented a at secondary school level, but need to be prepared early on. It is Necessary to develop a focused design of individual planning service activities as well as the achievement of each level of education from primary to secondary school. In the aspect of the counselor needs no assistance to develop the capacity to implement individual student planning. One of the recommendations for teacher mentoring models with models of jobs embedded professional development.

\section{CONCLUSION}

School counselors establish their identity and clearly articulate and define the role that school counseling programs play in promoting student achievement and educational success. New vision school counselors work intentionally with the expressed purpose of reducing environmental and institutional barriers that impede Academic and college/career planning provide all students with the opportunity to identify strengths, areas in need of improvement, and areas of interest early in their education, so students and their families can set postsecondary goals and make informed choices to support students in achieving their desired goals. The competence of school counselors as consultants for students in planning the future as well as collaborative competence with various parties in the success of academic studies of students in middle school.

\section{ACKNOWLEDGMENT}

Publication of the presented result has received funding from the Directorate of Research and Community Service, Directorate for Strengthening Research and Development, Ministry of Research, Technology and Higher Education under project no PKPT-062/SP3/III/2018. The content of this is part of a study on the Model Individual Student Planning for Academc Succes Study in Middle School.

\section{REFERENCES}

[1] P. M. Pendidikan and K. R. I. Nomor, "111 tahun 2014 tentang Bimbingan dan Konseling pada Pendidikan Dasar dan Pendidikan Menengah,” Jakarta: Depdikbud, 2015.

[2] M. Savitz-Romer and S. Bouffard, Ready, willing, and able: A developmental approach to college access and success. Harvard Education Press, 2012.

[3] N. C. Gysbers, "Individual student planning in the United States: Rationale, practices, and results," Asian J. Couns., vol. 15, no. 2, pp. 117-139, 2008.

[4] G. S. Johnson, "Individual Student Planning," in School Counselors as Practitioners, Routledge, 2018, pp. 83-106.

[5] R. E. Slavin, "Cooperative learning teori, riset dan praktik," Bandung Nusa Media, vol. 236, 2005.

[6] A. S. C. Association, ASCA National Model: A framework for school counseling programs. American School Counselor Association, 2012.

[7] S. Kalchik and K. M. Oertle, "The relationship of individual career plans to programs of study and career pathways," Transit. Highlights, vol. 3, 2011.

[8] E. Zamroni, D. Y. P. Sugiharto, and I. Tadjri, "Pengembangan Multimedia Interaktif Bimbingan Karir Untuk Meningkatkan Keterampilan Membuat keputusan Karir Pada program Peminatan Siswa SMP,” J. Bimbing. Konseling, vol. 3, no. 2, 2014.

[9] S. H. FANDINI and B. Purwoko, "Pengembangan Adobe Flash sebagai Media Layanan Informasi Peminatan Studi Lanjut SMA dan Sederajat Untuk Siswa Kelas IX SMPN 5 Sidoarjo,” J. BK UNESA, vol. 8, no. 1, 2018.

[10] F. L. Makrifah, "Pengembangan Paket Peminatan dalam Layanan Bimbingan Klasikal untuk Siswa di SMP," J. BK UNESA, vol. 4, no. 3, 2014.

[11] T. T. Atmaja, "Upaya meningkatkan perencanaan karir siswa melalui bimbingan karir dengan penggunaan media modul," PSIKOPEDAGOGIA J. Bimbing. dan Konseling, vol. 3, no. 2, pp. 5766, 2014.

[12] R. Lapan, "Comprehensive school counseling programs: In some schools for some students but not in all schools for all students." American School Counselor Association, 2012.

[13] S. C. Whiston and R. F. Quinby, "Review of school counseling outcome research,” Psychol. Sch., vol. 46, no. 3, pp. 267-272, 2009. 